\title{
Corrosion in Oil and Gas Industry: A Perspective on Corrosion Inhibitors
}

\author{
Mohammed Nuri Rahuma ${ }^{1,2}$ and Bobby Kannan $\mathbf{M}^{1 *}$ \\ ${ }^{1}$ College of Science, Technology and Engineering, James Cook University, Townsville, Queensland 4811, Australia \\ ${ }^{2}$ Faculty of Science, University of Benghazi, Benghazi, Libya
}

Corrosion is a common problem encountered in the oil and gas industry. Oil and gas pipelines, refineries and petrochemical plants have serious corrosion problems. Internal corrosion in oil and gas industry is generally caused by water, carbon dioxide $\left(\mathrm{CO}_{2}\right)$ and hydrogen sulfide $\left(\mathrm{H}_{2} \mathrm{~S}\right)$, and also can be aggravated by microbiological activity [1]. Importantly, the flow regimes of multiphase fluids greatly influence the corrosion rate. For example, at high flow rates, flowinduced corrosion and erosion-corrosion may occur, whereas at low flow rates, pitting corrosion is more common. Corrosion is generally related to the amount and nature of the sediments. High-velocity flow tends to sweep sediments out of the pipeline, whereas low velocity allows sediments to settle at the bottom, providing sites for pitting corrosion [2].

Combating corrosion in the oil and gas industry is paramount since the economic loss in these industries due to corrosion is extremely high [3]. Among the various methods to combat corrosion in oil and gas industry, the use of corrosion inhibitor is one of the best and economical methods $[4,5]$. There are many types of corrosion inhibitors, and they are broadly classified into anodic, cathodic or mixed corrosion inhibitor. There are also classifications based on their chemical nature, i.e., organic or inorganic inhibitors. However, the general inhibition mechanism is chemical adsorption (chemisorption) of the inhibitor on the surface of the metal and forms a protective thin film which protects the underlying metal from corrosion. The inhibitor may also increase the potential of the metal surface such that the metal enters the passivation region where a natural protective oxide film forms and/or the inhibitor may react with the corrosive component and remove it from the media [6].

Many of the commercial corrosion inhibitors used in the oil and gas industry are unique mixtures that may contain surfactants, film enhancers, demulsifies, or oxygen scavengers, in addition to the inhibitor moiety. The majority of the corrosion inhibitors used currently has nitrogen containing molecules. They can be classified into many groups, such as the amides/imidazolines, salts of nitrogenous molecules with carboxylic acids, nitrogen quaternaries, polyoxyalkylated amines, amides, imidazolines and nitrogen heterocyclics. Indeed, there are other non-nitrogenous inhibitors that contain phosphorous, sulphur, or oxygen atoms, but they are less frequently used [7].

In order to use corrosion inhibitors effectively in the oil and gas industry, the inhibitor must be compatible with the expected environment, economical, and not only provide great protection to the metal but also should not cause any significant undesirable side effects which might affect the operation/process. The properties of the "neat" inhibitor formulation, i.e., as received from the formulators, are important mainly from the standpoint of handling the material, the reaction of the inhibitor with other chemical like demulsifies, bactericides, scale inhibitors and dispersants [8]. The thermal stability of the inhibitor is also a critical property. Further, the effect of mixing the corrosion inhibitor with environment, i.e., its solubility, water tolerance, emulsion/foam formation, and the physical properties like drying, viscosity, pour point and density should be taken into consideration. For example, low viscosity of the inhibitor is essential to provide adequate pumping rates or flow rates. Often, the inhibitor is diluted prior to injection to improve its mobility, mainly during cold weather. In the oil and gas industry, it is critical to extend the life of equipment, prevent accidents and shutdown resulting from catastrophic mechanical failures, avoid product contamination and prevent loss of heat transfer. Potential savings for each of these goals must be evaluated to determine if a program of corrosion combating using inhibitors will be economical. There are several costs associated with the use of inhibitors. In fact, in addition to the inhibitor cost, the cost of installation of injection equipment, maintenance of injection equipment, purchase of inhibitor chemical(s), monitoring inhibitor concentration(s), system changes to accommodate the inhibitor, system cleaning, waste disposal and personnel safety equipment, must be factored into any economic evaluation of the use of corrosion inhibitors. Some costs are often difficult to estimate in the oil and gas industry, however the best way is to obtain data on maintenance, replacements etc. from the past and make judicious selections.

\section{References}

1. Ahmad I, Rahuma MN (2013) Corrosion mitigation and inspection strategy for pipeline integrity management: An experience of Sarir Oilfield. NACE International, Corrosion Conference and Expo.

2. Papavinasam S (2000) Corrosion Handbook. ( $2^{\text {nd }}$ edn), John Wiley \& Sons, Inc.

3. Santhana PS, Joseph RR, Dorothy R, Brindha G, Pandiarajan M, et al. (2014) Corrosion problems in petroleum industry and their solution. Eur Chem Bull 3: 300-307.

4. Miksic BM, Furman AY, Kharshan MA (2009) Effectiveness of the corrosion inhibitors for the petroleum industry under various flow conditions. NACE International, Corrosion Conference and Expo.

5. Rahuma MN, EL-Sabbah MB, Hamad IM (2013) Effect of serine and methionine on electrochemical behavior of the corrosion of mild steel in aqueous solutions. Hindawi Publishing Corporation, ISRN, Corrosion 2013:1-7.

6. Popoola LT, Grema AS, Latinwo GK, Gutti B, Balogun AS (2013) Corrosion problems during oil and gas production and its mitigation. International Journal of Industrial Chemistry, Springer Open Journal 4: 1-15.

7. Ahmad I, Rahuma MN, Knish A (2014) The nitrogenous corrosion inhibitors used in petroleum production. International Journal of Pharmaceutical and Chemical Sciences 3: 255-259.

8. Fink JK (2012) Petroleum engineer's guide to oil field chemicals and fluids Elsevier Inc.

*Corresponding author: Bobby Kannan M, College of Science, Technology and Engineering, James Cook University, Townsville, Queensland 4811, Australia, Tel: +61-7-4781-5080; Fax: +61-7-4781-6788; E-mail: bobby.mathan@jcu.edu.au

Received November 28, 2014; Accepted November 28, 2014; Published December 04, 2014

Citation: Rahuma MN, Bobby Kannan M (2014) Corrosion in Oil and Gas Industry: A Perspective on Corrosion Inhibitors. J Material Sci Eng 3: e110. doi:10.4172/21690022.1000e110

Copyright: (c) 2014 Rahuma MN, et al. This is an open-access article distributed under the terms of the Creative Commons Attribution License, which permits unrestricted use, distribution, and reproduction in any medium, provided the original author and source are credited. 